\title{
ANALYSING AND REDUCTION OF HAZARDOUS CONTENTS PRESENT IN THE ASH GENERATED FROM INDUSTRIAL WASTE THROUGH INCINERATION PROCESS
}

\author{
Prabaharan $\mathbf{T}^{1}$, Gowtham $\mathbf{M}^{2}$ \\ ${ }^{1}$ Senior Professor, Department of Mechanical Engineering, MepcoSchlenk Engineering College, Sivakasi \\ ${ }^{2}$ Student, Department of Mechanical Engineering, MepcoSchlenk Engineering College, Sivakasi
}

\begin{abstract}
Waste management is the major problem in all industry. Waste management is the disposal of waste generated from initial stage to the final stage of a manufacturing process. Wastes should be disposed in a safe and proper manner. There are several methods followed in the disposal of wastes. One of the methods is the incineration process. It involves the burning of solid waste in a controlled chamber. It converts the solid waste in to ash, flue gas and heat. The flue gas will be cleaned before released in to atmosphere. The bottom ash is disposed on ground and water without any treatment process. It may contain pollutants and metals which can affect the humans and environment. The heavy metals present in the incinerated bottom ash of industrial solid waste can affect the immune system and it is harmful for our human health. The main aim of this work is to identify the hazardous contents present in the bottom ash generated from incineration process of industrial waste and find treatment methods to eliminate or reduce the trace metals and pollutants. This work is to find a treatment method to protect the humans and environment from the effects of hazardous emissions from ash created from the incineration process of industrial solid waste.
\end{abstract}

Keywords: Waste management, industrial wastes, Heavy metals and treatment method etc

\section{INTRODUCTION}

Solid Waste management is the process of managing the wastes developed in any industries. It includes collection of waste, transportation, processing, and final disposal.It is the disposal of solid waste generated during the initial and final stage of a manufacturing process. There are several techniques followed in solid waste management. Incineration is one of the waste management technique. It is the process of burning the solid waste in a controlled chamber. It will produce heat, fly ash, bottom ash and gas. Incineration method can be used for large scale solid waste management. It will reduce the quantity of waste for morethan 80 percent. Flue gas and fly ash were disposed in to the atmosphere. Incinerator will release variety of pollutants depending on the type of waste. These pollutants can lead to health effects and environmental pollution. The Pollutants released are particulate matter, metals, acids, nitrogen, sulphur and some other toxic substances. This process of waste incineration creates a significant threat to public health and the environment. The major impact on health is the higher incidence of cancer and respiratory symptoms. The effect on the environmental is in the form of global warming, acidification, photochemical ozone or smog formation, eutrophication, and human and animal toxicity. The main aim of this work is to identify the hazardous contents in the bottom ash generated from incineration process of industrial waste and find treatment methods to eliminate or reduce those contents. This work is to find a method to save the humans and environment from the effects of hazardous emissions from ash created from the incineration process of solid waste.

\section{RELATED STUDY}

For decades, incineration was the method of choice for the treatment of such infectious wastes. Incinerator releases a wide variety of pollutants depending on the composition of the waste, which leads to health deterioration and environmental degradation. The significant pollutants emitted are particulate matter, metals, acid aside from the release of innumerable substances of unknown toxicity. The use of hydroclaves and plasma pyrolysis for the incineration of wastes leads to lesser environmental degradation, negligible health impacts, safe handling of treated wastes, lesser running and maintenance costs, more effective reduction of microorganisms, and safer disposal. [1]. The environmental impact of pulp and paper manufacture results mainly from wood pulping and pulp bleaching processes. The pollutants are represented by sulphur compounds and nitrogen oxides that are emitted to the air, and by bleaching chlorinated and organic compounds and nutrients that are discharged to the wastewaters and land. Wood wastes and sludge represent the most important residues of a pulp and paper mill.[2]Two Treatment solutions were experimentally investigated as potential chemical fixation agents for trace elements present in fly ash collected at four different sites located in the south eastern united states. Both treatment solutions contained the same concentration of ferrous sulphate, but calcium carbonate was added to the second 
solution to buffer the $\mathrm{pH}$.[3]. The objectives of the solidification/stabilization treatment were therefore to reduce the leachability of the heavy metals present in these materials so as to permit their disposal in a sanitary landfill requiring only a lower degree of environmental protection. Another objective of the applied treatment was to increase the mechanical characteristics of the bottom ash using different amounts of Ordinary Portland Cement (OPC) as a binder. The solidified matrix showed that the cement is able to immobilize the heavy metals found in fly and bottom ash. [4]

\section{WORK DESCRIPTION}

Improper disposal of solid waste can create unsanitary conditions and these conditions can lead to pollution of the environment and can cause health problems by Pollutants. The solid waste collected from industries may contain hazardous materials. The incineration of these wastes can produce gases and ash which affects the environment. The presence of heavy metals in the bottom ash will affect both the human health and the environment. It can affect the atmospheric air quality. Toxic gases may release and affects the humans and other living beings. Water quality and soil quality will be affected if it is disposed on the ground. This work aims to analyse and reduce the hazardous content present in the ash generated from industrial waste through incineration process. The methodology of this work is described below. The solid wastes from different industries (paper pulp industry and printing industry) were collected. The next step is the incineration of waste. The bottom ash generated in the incineration process is collected. The collected bottom ash will be tested to find the contents and its properties. To Test the bottom ash contents, Inductively Coupled Plasma Test and $\mathrm{pH}$ test was taken. Then it is analysed and the hazardous materials present in the ash will be found out. Based on the contents found, the available treatment methods were studied and the suitable treatment method is selected. I have used Solidification/Stabilization and chemical treatment methods for the ash treatment. Then the incinerated bottom ash collected from two different industries will be treated with the selected treatment metals to remove the trace elements present in the ash. After the treatment of ash, again the tests will be taken to find the level of metals in the ash. The results of treated and untreated ash samples will be compared to analyse the effectiveness of the treatment methods.

\section{TREATMENT METHODS}

\subsection{Solidification $\backslash$ Stabilization}

Solidification/Stabilization is a process using additives to reduce the hazardous nature of a waste by converting the waste and its hazardous contents into a form that minimizes the rate of contaminant or reduces the level of toxicity. It uses additives or binders to stabilize the metals present in the waste. The objective of the solidification process is to reduce the leachability of the heavy metals present in the materials for the safe disposal in to the landfill. It will also increase the mechanical properties of the bottom ash if Portland cement is used as a binding material. The cement is able to immobilize the heavy metals present in the bottom ash.

\subsection{Chemical Treatment}

Chemical treatment of hazardous waste refers to the treatment methods that are used to effect the complete breakdown of hazardous waste into non-toxic gases or, more frequently, to modify the chemical properties of the waste, for example, through reduction of water solubility or neutralisation of acidity or alkalinity.

\section{Ferrous Sulphate Treatment}

The ash samples were treated with a ferrous sulphate solution at solid:liquid ratios of 1:3. The ash samples were mixed with ferrous sulphate solution and stirred for 15 minutes. Then the treated ash samples were allowed to dry for 1 week in open air. After a week, the ash samples will be taken for further testing.

\section{Ferrous Sulphate with Calcium Carbonate buffer}

\section{Treatment}

Additional batch experiments were conducted in which each fly ash sample was treated with ferrous sulphate solution and $1.5 \mathrm{~g}$ of added solid calcium carbonate. The calcium carbonate was used to buffer the solution $\mathrm{pH}$ during treatment in order to increase the precipitation of ferric hydroxide. The treatment was carried out using the same conditions and procedures described in the previous section. The Treated ash samples were allowed to air dry for 1 week.

\section{RESULTS AND DISCUSSIONS}

\subsection{Solidification/Stabilization Process}

In this process, the bottom ash generated from two industrial solid wastes were taken. In Solidification/ Stabilization process, a binder is used to stablilize the heavy metals present in the ash. In my work, I have used epoxy as a binding material for paper pulp ash and Portland cement is used as a binders for printing waste ash. The bottom ash of paper pulp waste was mixed with epoxy and the bottom ash of printing waste was mixed with a Portland cement. The ash is kept mixed with binders for 10 days as a hydration period. After 10 days, the treated ash samples were taken and further tests are carried out. Then the results will be compared with the untreated ash samples. If the Portland cement is used as a binding material, the ash can be reused for construction work. The ash mixed with the cement will increase the mechanical properties and it will give good strength 
Table 1: Solidification/Stabilization

\begin{tabular}{|l|l|l|l|}
\hline Sample(Ash) & Metals & Binders & Period \\
\hline Paper Pulp & $\begin{array}{l}\text { Zn, Cu, Epoxy } \\
\text { Cr, Pb }\end{array}$ & 10 days \\
\hline Printing Waste & $\begin{array}{l}\text { Pb, Hg, } \\
\text { Cr, Cd }\end{array}$ & $\begin{array}{l}\text { Portland } \\
\text { cement }\end{array}$ & 10 days \\
\hline
\end{tabular}

\subsubsection{ICP Results after Solidification Process}

The two ash samples were treated by the solidification process. The main purpose of the treatment is to remove or reduce the heavy metals present in the samples. ICP test was taken for the two treated ash samples to measure the level of heavy metals present after the treatment process. The ICP results are shown in the table.

\section{Sample 1- Paper Pulp Waste}

Table2: ICP Result of Sample 1

\begin{tabular}{|l|l|l|l|}
\hline \multirow{2}{*}{ Metals } & \multicolumn{2}{|l|}{$\begin{array}{l}\text { Concentration } \\
(\mathrm{mg} / \mathrm{l})\end{array}$} & $\begin{array}{l}\text { Permissible } \\
\text { Level (mg/l) }\end{array}$ \\
\cline { 2 - 3 } & Before & After & \\
\hline Zn & 6.1 & 3.3 & 5 \\
\hline Cu & 1.8 & 0.9 & 1.3 \\
\hline Cr & 0.71 & 0.52 & 0.1 \\
\hline Pb & 0.1 & 0.075 & $\mathbf{0 . 0 1 5}$ \\
\hline Cd & 0.003 & $\mathbf{0 . 0 0 1}$ & $\mathbf{0 . 0 0 5}$ \\
\hline
\end{tabular}

\section{Sample2- Printing Waste}

Table 3: ICP Result of Sample 2

\begin{tabular}{|l|l|l|l|}
\hline \multirow{2}{*}{ Metals } & \multicolumn{2}{|l|}{$\begin{array}{l}\text { Concentration } \\
(\mathrm{mg} / \mathrm{l})\end{array}$} & $\begin{array}{l}\text { Permissible } \\
\text { Level (mg/l) }\end{array}$ \\
\cline { 2 - 3 } & Before & After & \\
\hline $\mathrm{Pb}$ & $\mathbf{0 . 0 5 6}$ & $\mathbf{0 . 0 2 3}$ & $\mathbf{0 . 0 1 5}$ \\
\hline $\mathrm{Hg}$ & $\mathbf{0 . 0 1 6}$ & $\mathbf{0 . 0 0 9}$ & $\mathbf{0 . 0 0 2}$ \\
\hline $\mathrm{Cr}$ & $\mathbf{0 . 4}$ & $\mathbf{0 . 3 1}$ & $\mathbf{0 . 1}$ \\
\hline $\mathrm{Cd}$ & $\mathbf{0 . 0 1 5}$ & $\mathbf{0 . 0 1 6}$ & $\mathbf{0 . 0 0 5}$ \\
\hline $\mathrm{Ni}$ & $\mathbf{2 . 1}$ & 1.7 & $\mathbf{1 . 0}$ \\
\hline
\end{tabular}

From the above ICP results taken for the treated and untreated ash samples, we can found that the heavy metals concentration present in the incinerated bottom ash of paper pulp waste and printing waste has been reduced after the Solidification/Stabilization process. The metals such as Zn, $\mathrm{Cu}, \mathrm{Cd}$ has been limited to the standard permissible level. But the metals such as $\mathrm{Cr}, \mathrm{Pb}, \mathrm{Ni}$ were present slightly more than the permissible level. So, we have to go for further treatment process to reduce those elements which is more than the standard permissible levels.

\subsection{Chemical Treatment Process}

To reduce the trace elements present after the solidification process, a Chemical treatment is used. Ferrous sulphate solution is used to stabilize the metals which is present more than the permissible level. The ash samples were mixed with ferrous sulphate solution and stirred for 15 mins. After that process, the ash samples were allowed to dry for 1 week in open air.

After a week, the chemically treated ash is again treated with ferrous sulphate solution with calcium carbonate. The ash is treated with ferrous sulphate solution and $1.5 \mathrm{~g}$ of added solid calcium carbonate. The calcium carbonate was used to buffer the solution $\mathrm{pH}$ during treatment in order to increase the precipitation of ferric hydroxide. The treatment was carried out using the same conditions and procedures. The Treated ash samples were allowed to air dry for 1 week

\subsubsection{ICP Results}

The ICP results taken after the solidification process shows that the metals $\mathrm{Cr}, \mathrm{Pb}$, Ni were present slightly more than the permitted levels. So, the ash samples were again chemically treated with ferrous sulphate and calcium carbonate. After the chemical treatment, the ICP test was taken. The results are shown in the table below.

\section{Sample 1- Paper Pulp}

Table 4: Paper Pulp Ash

\begin{tabular}{|l|l|l|l|}
\hline \multirow{2}{*}{ Metals } & \multicolumn{2}{|l|}{$\begin{array}{l}\text { Concentration } \\
(\mathbf{m g} / \mathbf{l})\end{array}$} & \multirow{2}{*}{$\begin{array}{l}\text { Permissible level } \\
\text { (mg/l) }\end{array}$} \\
\cline { 2 - 3 } & Before & After & \\
\hline $\mathrm{Cr}$ & $\mathbf{0 . 3 1}$ & $\mathbf{0 . 1 3}$ & $\mathbf{0 . 1}$ \\
\hline $\mathrm{Pb}$ & $\mathbf{0 . 0 7 5}$ & $\mathbf{0 . 0 1 9}$ & $\mathbf{0 . 0 1 5}$ \\
\hline
\end{tabular}

\section{Sample 2- Printing waste}

Table 5: Printing Waste Ash

\begin{tabular}{|l|l|l|l|}
\hline \multirow{2}{*}{ Metals } & \multicolumn{2}{|l|}{$\begin{array}{l}\text { Concentration } \\
(\mathrm{mg} / \mathrm{l})\end{array}$} & $\begin{array}{l}\text { Permissible } \\
\text { level }(\mathrm{mg} / \mathrm{l})\end{array}$ \\
\cline { 2 - 3 } & Before & After & \\
\hline $\mathrm{Cr}$ & $\mathbf{0 . 5 2}$ & $\mathbf{0 . 1 3}$ & $\mathbf{0 . 1}$ \\
\hline $\mathrm{Ni}$ & 1.7 & $\mathbf{0 . 7 8}$ & $\mathbf{1 . 0}$ \\
\hline $\mathrm{Pb}$ & $\mathbf{0 . 0 2 3}$ & $\mathbf{0 . 0 1 9}$ & $\mathbf{0 . 0 1 5}$ \\
\hline
\end{tabular}

From the above ICP results of ash taken after chemical treatment, we can say that the concentration of metals $\mathrm{Cr}$, $\mathrm{Ni}, \mathrm{Pb}$ has been reduced. $\mathrm{Cr}$, Ni has been limited to the standard permissible level and the concentration of $\mathrm{Pb}$ is slightly more than the permissible level.

\subsection{FTIR Analysis}

Fourier Transform Infrared Spectroscopy is an analytical technique used to identify organic, polymeric, and, in some cases, inorganic materials. The FTIR analysis method uses infrared light to scan test samples and observe chemical properties. After the two treatment process, the FTIR analysis was taken for the two ash samples to find out the functional groups present in the ash. The FTIR results are shown below. 


\section{Sample 1- Paper Pulp Waste Ash}

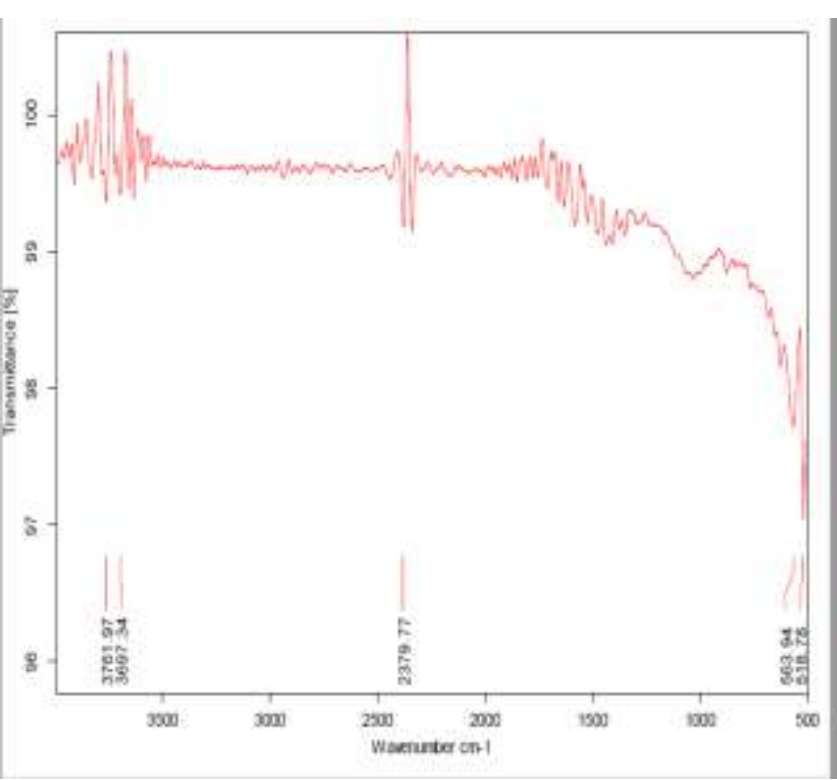

Fig 1: FTIR of Sample 1

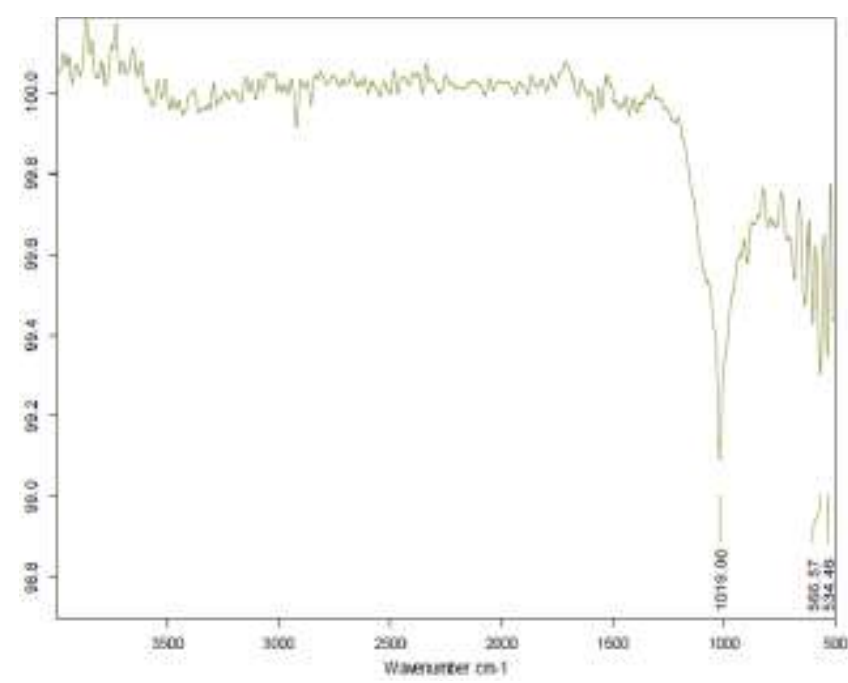

Fig 2: FTIR of Sample 2

From the above results, in the sample 1 silane groups are present. In sample 2, Silane and amine groups are present. Amines are organic molecules containing nitrogen and are relatives of ammonia. In amines one of the hydrogen atoms on the nitrogen is replaced with a hydrocarbon group. Depending on how many hydrogen have been replaced by the hydrocarbon group they have been classified into Primary, secondary and tertiary amines. Amine themselves are not harmful but they can react with other compounds. It may affect the environment and humans. But no proven studies are there on the toxic effects of these amines.

\section{$5.4 \mathrm{pH}$ Result}

The $\mathrm{pH}$ test was taken for the two treated ash samples. The $\mathrm{pH}$ values taken after the ash treatment is shown in the table and it is compared with the untreated ash samples.
Table 6: $\mathrm{pH}$ Result

\begin{tabular}{|l|l|l|}
\hline Sample & pH & \\
\cline { 2 - 4 } & Before & After \\
\hline $\begin{array}{l}\text { Paper Pulp Ash (s/s } \\
\text { process) }\end{array}$ & 2.5 & 4.6 \\
\hline $\begin{array}{l}\text { Printing Waste Ash (s/s } \\
\text { process) }\end{array}$ & 4.2 & 7.2 \\
\hline $\begin{array}{l}\text { Paper Pulp (chemical } \\
\text { treatment) }\end{array}$ & 2.1 & 5.5 \\
\hline $\begin{array}{l}\text { Printing Waste (chemical } \\
\text { treatment) }\end{array}$ & 9.5 & 7.6 \\
\hline
\end{tabular}

$\mathrm{pH}$ is used to identify the acid or alkaline condition of a solution. It is a way of expressing the hydrogen ion concentration. The $\mathrm{pH}$ value ranges from 0 to 14 . The value of 0 to 7 indicates the acidic condition and the value between 7 to 14 indicates alkalinity. The value below 2 is more acidic and the value above 9 is more alkaline. The Acidic $\mathrm{pH}$ affects the amount of nutrients and chemicals that are soluble in soil water, and therefore the amount of nutrients available to plants will be less. The acidic condition affects the soil and water bodies. Most of the nutrients are available when the $\mathrm{pH}$ is near neutral. So the $\mathrm{pH}$ should be between 2 to 9 . In this work, the $\mathrm{pH}$ was measured for the treated and untreated Ash samples. The $\mathrm{pH}$ level of both the ash samples ranges between 2 to 9 after the two different treatment methods.

\subsection{Chemical Oxygen Demand}

Chemical Oxygen Demand is the measurement of total chemicals present in the water. A COD test will be used to measure and quantify the amount of organics present in the water. After the disposal of ash in ground, it may be mixed with underground water or water bodies. So, we have to ensure the safe limit of chemicals or pollutants present in the ash. So, Chemical Oxygen demand test was taken to measure the pollutants present in the water containg the ash.

Table 7: COD

\begin{tabular}{|c|c|c|c|}
\hline S.No & Sample & $\begin{array}{l}\text { C.O.D } \\
(\mathrm{mg} / \mathrm{l})\end{array}$ & $\begin{array}{l}\text { Permissible } \\
\text { level }(\mathrm{mg} / \mathrm{l})\end{array}$ \\
\hline 1 & $\begin{array}{l}\text { Paper Pulp } \\
\text { Waste(S\S } \\
\text { process) }\end{array}$ & 226 & 250 \\
\hline 2 & $\begin{array}{l}\text { Printing } \\
\text { Waste(S/S } \\
\text { process) } \\
\end{array}$ & 247 & 250 \\
\hline 3 & $\begin{array}{l}\text { Paper Pulp } \\
\text { waste(Chemical } \\
\text { Treatment) }\end{array}$ & 236 & 250 \\
\hline 4 & $\begin{array}{l}\text { Printing Waste } \\
\text { (Chemical } \\
\text { treatment) }\end{array}$ & 251 & 250 \\
\hline
\end{tabular}

The main purpose of conducting COD test is to measure the amount of oxidisable pollutants present in the waste water. COD is used to find the quality of water by giving an metric to determine the effect of a waste water. Here, the purpose 
of taking COD test is to check the quality of water if the incinerated bottom ash after treatment may be disposed in a water bodies. The results obtained after Solidification process and Chemical treatment for Chemical Oxygen Demand is about $225 \mathrm{mg} / \mathrm{l}$ to $250 \mathrm{mg} / \mathrm{l}$ for all the ash samples. The permissible level of COD in water bodies is $250 \mathrm{mg} / 1$.

\subsection{Dissolved Oxygen}

Dissolved Oxygen is the amount of gaseous oxygen dissolved in the water. The oxygen level in the water should be maintained with in the adequate level for the aquatic animals and plants to survive. The Dissolved Oxygen was measured for the two treated ash samples and the results are shown in the table.

Table 8: DO

\begin{tabular}{|c|c|c|c|}
\hline S.No & Sample & $\begin{array}{l}\text { D.O } \\
(\mathrm{mg} / \mathrm{l})\end{array}$ & $\begin{array}{l}\text { Required } \\
\text { level }(\mathrm{mg} / \mathrm{l})\end{array}$ \\
\hline 1 & $\begin{array}{lr}\text { Paper } & \text { Pulp } \\
\text { Waste } & \text { (S/S } \\
\text { Process) } & \\
\end{array}$ & 7.62 & 5 to 7 \\
\hline 2 & $\begin{array}{l}\text { Printing } \\
\text { Waste(S/S } \\
\text { process) } \\
\end{array}$ & 6.25 & 5 to 7 \\
\hline 3 & $\begin{array}{l}\text { Paper Pulp } \\
\text { waste(Chemical } \\
\text { Treatment) }\end{array}$ & 7.15 & 5 to 7 \\
\hline 4 & $\begin{array}{l}\text { Printing Waste } \\
\text { (Chemical } \\
\text { treatment) }\end{array}$ & 6.81 & 5 to 7 \\
\hline
\end{tabular}

According to the indian standard, the oxygen level in the waster should be minimum of $5 \mathrm{mg} / \mathrm{l}$ and it should not be more than $7 \mathrm{mg} / \mathrm{l}$. The Dissolved Oxygen of paper pulp waste ash and printing waste ash is about $6 \mathrm{mg} / \mathrm{l}$ to $7 \mathrm{mg} / \mathrm{l}$.

\section{CONCLUSION}

In this work, the incineration bottom ash obtained from the combustion of paper mill sludge and printing industry waste was analysed and the results are discussed. From the results, it is find that the presence of heavy metals in the bottom ash is more than the permissible limits. These heavy metals will cause health problems to humans and it will contaminate the soil and affects the water quality, air quality. The $\mathrm{pH}$ result shows the acidic condition of bottom ash. The acids in the soil affects the plant growth and affects human health. So the bottom ash should not be disposed on lands and water without the reduction of the hazardous contents. Solidification/Stabilization and Chemical Treatment methods were used to stabilize the trace metals present in the ash and to reduce the acidic nature of the ash. The results taken after the treatment shows that the hazardous metals in the bottom ash has been limited to the permissible level and the $\mathrm{pH}$, Chemical Oxygen demand and Dissolved Oxygen measurements shows that the ash can be safely disposed.

\section{REFERENCES}

[1] Raman Sharma ,Meenakshi Sharma , Ratika Sharma and Vivek Sharma-Rev Environmental Health-"The impact of incinerators on human health and environment"; Vol 28(1): pp 67-72- 2013

[2] Dan Gavrilescu1, Adrian Catalin-Environmental Safety-"Environmental impacts of Pulp and paper mill"- Vol 4-pp-698-705- 2010

[3] Rona J. Donahoe, Sidhartha Bhattacharyya, Dan Patel-World of Coal Ash-"Chemical Fixation of trace elements in Coal Fly Ash"- 2007

[4] KalliopiAnastasiadou, Konstantinos Christopoulos, Epameinonta, Mousios, Evangelos Gidarakos-Journal of hazardous materials-"Solidification/stabilization of fly and bottom ash from waste incineration facility" pp165-170-2012. 